\title{
First China-Russia International Meeting on the Central Asian Orogenic Belt and IGCP-592 Workshop
}

\author{
Inna Safonova $^{\mathrm{a}, \mathrm{b}}$, Tao Wang ${ }^{\mathrm{c}, \mathrm{d}}$, Bei Xu $^{\mathrm{e}}$, Dmitrii Gladkochub ${ }^{\mathrm{f}}$, Ying Tong ${ }^{\mathrm{c}}$ \\ ${ }^{\text {a }}$ Institute of Geology and Mineralogy SB RAS, Koptyuga ave. 3, Novosibirsk, 630090, Russia \\ ${ }^{\mathrm{b}}$ Novosibirsk State University, Pirogova St. 2, Novosibirsk, 630090, Russia \\ ${ }^{c}$ Institute of Geology, Chinese Academy of Geological Sciences, 100037 Beijing, China \\ ${ }^{d}$ Xi' an Center of Geological Survey, China Geological Survey, Xi' an 710054, China \\ ${ }^{\mathrm{e}}$ Key Laboratory of Orogenic Belts and Crustal Evolution, Peking University, Beijing, 100871, China \\ ${ }^{\mathrm{f}}$ Institute of the Earth's Crust SB RAS, 128 Lermontova St., Irkutsk 664033, Russia
}

The Central Asian Orogenic Belt (CAOB), the Earth's largest Phanerozoic accretionary orogenic belt, is located between the Siberian, Tarim and North China Cratons and the Kazakhstan composite continent (Fig. 1a). It is ca. $800 \mathrm{~km}$ wide and extends from the Ural Mountains in the west to the Pacific in the east (e.g., Zonenshain et al., 1990; Mossakovsky et al., 1993; Jahn et al., 2000; Windley et al., 2007, Xiao et al., 2010; Safonova et al., 2011). In the past two decades, many studies have shown that the CAOB is composed of many terranes of different tectonic origins, and was formed by successive accretion of terranes, microcontinents, island arcs, seamounts, ophiolites, and accretionary prisms from the early Neoproterozoic to the late Palaeozoic (e.g., Mossakovsky et al., 1994; Badarch et al., 2002; Xiao et al., 2003; Buslov et al., 2001; Kovalenko et al., 2004; Safonova, 2009; Li, 2006; Kröner et al., 2007, 2014; Donskaya et al., 2013; Xu et al., 2013). It also documents global massive generation of juvenile crust and a giant metallogenic belt during the Phanerozoic (e.g., Hong et al., 1996; 2004; Han et al., 1997; Jahn et al., 2000; Wang et al., 2009). As such, it provides a chance to study the processes and patterns of an accretionary orogenic belt and continental growth. To understand these processes is one of the major issues of the geology of Asia and has global significance. Many studies and major projects have been carried out on CAOB including four IGCP projects: \#420 (B.-m. Jahn, D.-w. Hong), \#473 (R. Seltmann, J.-w. Mao), \#480 (B. Natal'in, C. Sengor, A. Yin) and \#592 (I. Safonova, R. Seltmann, M. Sun, W. Xiao). In 2013, a study of the tectonic evolution of the southern CAOB occupied the first place of five research fronts in the earth sciences identified by the publisher Elsevier Ltd.

The CAOB extends across Russia, China, Kazakhstan, Kyrgyzstan, Uzbekistan, Tajikistan and Mongolia. Due to its huge size, extensive and intensive international cooperation researches and, particularly, across-border comparative studies are necessary to improve our understanding of its long and complex evolution. Consequently, CAOB geologists all agree that it is necessary to build a platform of communication between researchers from Russia, China and other countries to exchange new data and ideas and to discuss and plan future cooperative projects.

The Institute of Geology, Chinese Academy of Geological Sciences (CAGS) in Beijing and the Institute of the Earth's Crust, Siberian Branch of the Russian Academy of Sciences (RAS) in Irkutsk in cooperation with major projects such as IGCP Project 592 "Continental construction in the Central Asian Orogenic Belt compared with actualistic examples from the western Pacific" supported by UNESCO-IUGS (https://sites.google.com/site/igcp592), the Major State Basic Research Program (973) of China, the Project of Compilation of Geological Maps of Central Asian by Five Asian Countries, and a Major Program of the National Natural Science Foundation of China organized "First China-Russia International Meeting and IGCP\#592 Workshop", which was held on September 23-25, 2015, in Beijing, China, and was followed by a post-conference
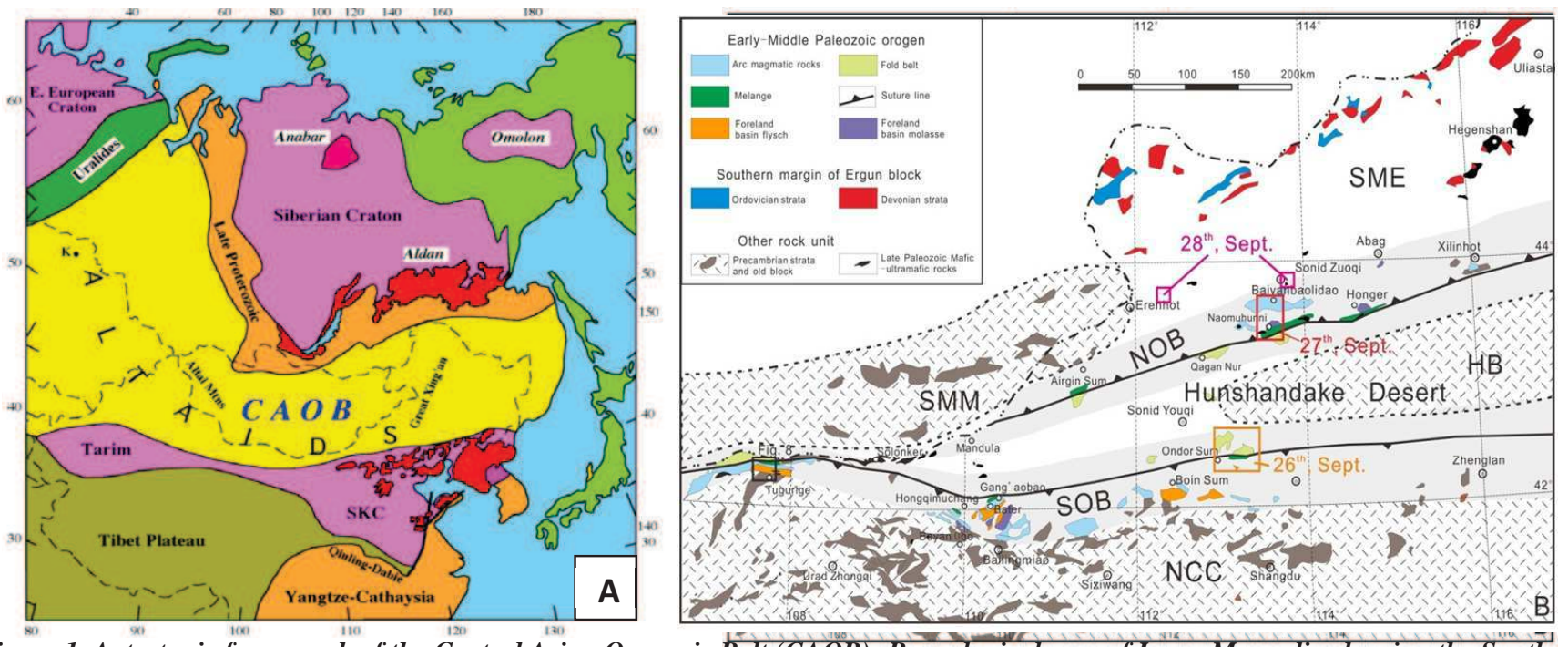

Figure 1. A, tectonic framework of the Central Asian Orogenic Belt (CAOB); B, geological map of Inner Mongolia showing the Southern (SOB) and Northern (NOB) orogenic belts (after Xu et al., 2013). 


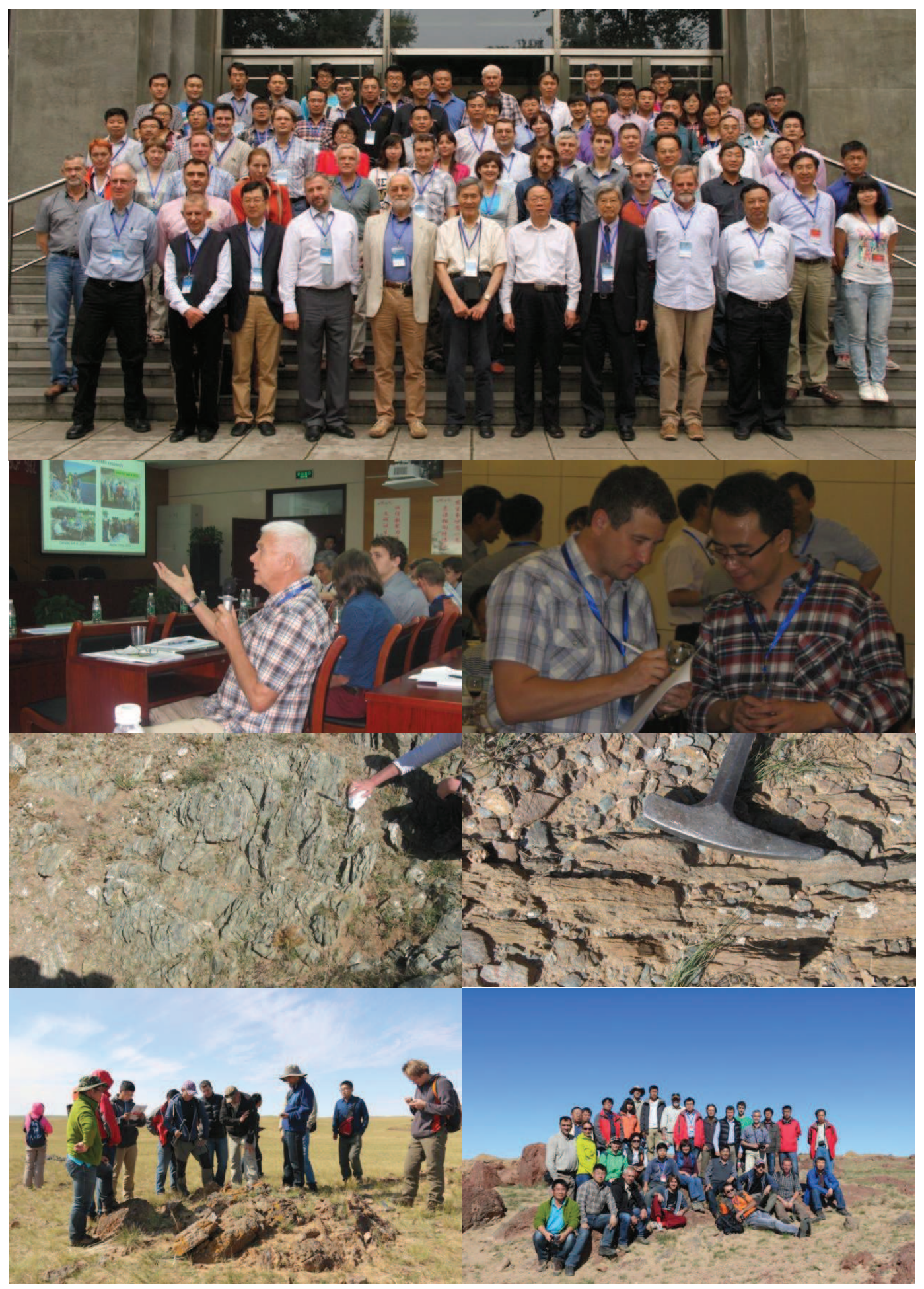

Figure 2. Photos from the $1^{\text {st }}$ China-Russian meeting on the CAOB and IGCP\#592 Workshop and the post-meeting field trip. A, group photo in front of the Institute of Geology, CAGS; B, Prof. A. Kröner: "Nobody has proved that Rodinia ever existed!"; C, establishing cooperative links: Drs. Alexei Ivanov from Irkutsk and Pengfei Li); D, turbiditic sandstone of the Ondor-Sum suture; E, Ondor-Sum blueschist; F, a hot discussion at an outcrop: rhodingite or not?; G, group photo at an outcrop of Erenhot alkaline granite.

field excursion to Inner Mongolia (Fig. 1). This meeting provided a forum to compare the previous tectonic and palaeogeographic models of the CAOB developed by Chinese, Russian and other research teams, to present new data and evolutionary models, and to discuss future international cooperation in the fields of geology, geochemistry, geophysics and other field of Earth sciences (Fig. 2a).
The participants made 34 oral and 13 poster presentations (Fig. 2b) during the workshop on six major topics: (1) evolution of the Palaeo-Asian Ocean: from accretion to collision (ophiolites, ocean plate stratigraphy, tectonics, magmatism, metamorphism and deformation styles); (2) across-border correlations in the CAOB and nomenclature; (3) continental crustal growth and architecture; (4) 
intra-plate processes and mantel plumes; (5) Mineralization in Central Asia; (6) superposition of the Palaeo-Pacific and Okhotsk tectonics; (6) continental amalgamation in the CAOB, Neoproterozoic to Palaeozoic palaeogeography and palaeomagnetism. The in-session and post-session discussion provided closer cooperation between the Chinese and Russian colleagues (Fig. 2c).

The post-meeting field trip was to Central Inner Mongolia in the eastern $\mathrm{CAOB}$, where the North China craton (NCC) is adjacent to the South Mongolian microcontinent (SMM). This region consists of several terranes (e.g., Xiao et al., 2003; Xu et al., 2013), including the Solonker ophiolite in the west and the north Hegenshan and south Linxi-Xar Moron ophiolites and the Xilinhot Xilin Gol microcontinent in the east (Fig. 1b). During the field trip the participants visited the Ondor-Sum subduction-accretion complex of the southern orogenic belt (SOB) and various terranes of the northern orogenic belt (NOB). More specifically, the participants observed (i) the Tulinkai ophiolite mélange of early Paleozoic age, (ii) Ondor-Sum blueschists (Ordovician; de Jong et al., 2006), (iii) the Ulan accretionary complex of Permian age of the SOB and (iv) the Naomuhunni mélange (Middle Devonian; Xu et al., 2013); (v) Ondor-Sum Group accretionary wedge (early Paleozoic), (vi) late Devonian mélange and molasses, (vii) the Precambrian basement and an early Paleozoic arc of the Sonid Zuoqi section, and (viii) Permian alkaline granite of the NOB (Fig. 2d-g). The participants discussed en-route many important problems of structure, tectonics, stratigraphy and magmatism of the Ondor-Sum suture, the closure of the Paleo-Asian Ocean and initiation of intracontinental bimodal volcanism in Permian time. The hot discussions (Fig. 2f) touched many important problems such as overindulgence to geochemical data, the necessity of careful field study to test the currently available models of the Ondor-Sum accretionary complex, presence of OPS units in accretionary complexes (Fig. 2d, e), precise timing of ocean closure and initiation of intra-plate magmatism, etc. General recommendations were to highlight the most important recently obtained structural, petrologic and geochronological data from the Northern and Southern Orogens of Inner Mongolia, to correlate them with similar coeval terranes in other segments of the CAOB, in particular, in Mongolia and Russia, and to publish the most hotly debatable questions of its geological history in a special research paper. Thus the First China-Russia meeting on the CAOB created and provided a new platform of communication for all geologists studying the CAOB. Hopefully those meetings will become regular and attract more participants from Russia, China and other countries in future. Supported by the Ministry of Education and Science of the Russian Federation (project no. 14.B25.31.0032). Contribution to IGCP\#592 sponsored by UNESCO-IUGS.

\section{References}

Badarch, G., Cunningham, W.D., Windley, B.F., 2002. A new terrane subdivision for Mongolia: implications for the Phanerozoic crustal growth of Central Asia. Journal of Asian Earth Sciences 21, 87-110.

Buslov, M.M., Saphonova, I.Yu, Watanabe, T., Obut, O.T., Fujiwara, Y., Iwata, K., Semakov, N.N., Sugai, Y., Smirnova, L.V., Kazansky, A.Yu., and Itaya, T., 2001, Evolution of the Paleo-Asian Ocean (Altai-Sayan, Central Asia) and collision of possible Gondwana-derived terranes with the southern marginal part of the Siberian continent: Geoscience Journal, 5(3), 203224.

de Jong, K., Xiao, W., Windley, B.F., Masago, H., and Lo, C.-h., 2006. Ordovician 40Ar/39Ar phengite ages from the blueschist-facies Ondor Sum subduction-accretion complex (Inner Mongolia) and implications for the early Paleozoic history of continental blocks in China and adjacent areas. American Journal of Science 306, 799-845.
Donskaya, T. V., Gladkochub, D. P., Mazukabzov, A. M., Ivanov, A. V., 2013. Late Paleozoic - Mesozoic subduction-related magmatism at the southern margin of the Siberian continent and the 150 million-year history of the Mongol-Okhotsk Ocean. Journal of Asian Earth Sciences, 62, 79-97.

Han, B.F.,Wang, S.G., Jahn, B.M., Hong, D.W., Kagami, H., Sun, Y.L., 1997. Depleted-mantle magma source for the Ulungur River A-type granites from north Xinjiang China:geochemical and $\mathrm{Nd}-\mathrm{Sr}$ isotopic evidence, and implication for Phanerozoic crustal growth. Chemical Geology, 138, $135-159$.

Hong, D.W., Wang, S.G., Han, B.F., Jin, M.Y., 1996. Post-orogenic alkaline granites from China and comparisons with anorogenic alkaline granites elsewhere. Journal of Southeast Asian Earth Sciences, 30( 1), 13-27. doi:10.1016/0743-9547(96)00002-5.

Hong, D.W.,Wang, S.G., Xie, X.L., Zhang, J.S.,Wang, T., 2004. Continental crustal growth and the supercontinental cycle: evidence from the Central Asian Orogenic Belt. Journal of Asian Earth Sciences, 23 (5), 799-813.

Jahn, B. M., Wu, F. Y., Chen, B., 2000.Granitoids of the Central Asian Orogenic belt and continental growth in the Phanerozoic, Transactions Royal Society of Edinburgh. Earth Sciences, 91(1-2), 181-193.

Kovalenko, V. I., Yarmolyuk, V. V., Kovach, V. P., Kotov, A. B., Kozlovsky, A. M., Salnikova, E. B., Larin, A. M., 2004, Isotope provinces, mechanisms of generation and sources of the continental crust in the Central Asian Mobile Belt: geological and isotopic evidence. Journal of Asian Earth Sciences, 23(5), pp. 605-627.

Kröner, A., Windley, B.F., Badarch, G., Tomurtogoo, O., Hegner, E., Jahn, B.M., Gruschka, S., Khain, E.V., Demoux, A., and Wingate, M.T.D., 2007, Accretionary growth and crust-formation in the central Asian Orogenic Belt and comparison with the Arabian-Nubian shield, in Hatcher, Jr., R.D., Carlson, M.P., McBride, J.H., Catalan, J.M., eds., The 4-D Framework of the Continental Crust-Integrating Crustal Processes through Time: Geological Society of America Memoir, 200, 181-209.

Kröner, A., Kovach, V., Belousova, E., Hegner, E., Armstrong, R., Dolgopolova, A., Seltmann, R., Alexeiev, D.V., Hoffmann, J.E., Wong, J., M. Sun, Cai, K., Wang, T., Tong, Y., Wilde, S.A., Degtyarev, K.E., and Rytsk, E., 2014, Reassessment of continental growth during the accretionary history of the Central Asian Orogenic Belt: Gondwana Research, 25, 103-125.

Li, J.-Y., 2006. Permian geodynamic setting of Northeast China and adjacent regions: closure of the Paleo-Asian Ocean and subduction of the PaleoPacific Plate. Journal of Asian Earth Sciences 26, 207-224.

Mossakovsky, A.A., Ruzhentsev, S.V., Samygin, S.G. and Kheraskova, T.N., 1993. The Central Asian foldbelt: geodynamics evolution and the history of formation. Geotektonika, no. 6, 33 (in Russian).

Safonova, I., Seltmann, R., Kröner, A., Gladkochub, D., Schulmann, K., Xiao, W., Kim, T., Komiya, T., and Sun, M., 2011, A new concept of continental construction in the Central Asian Orogenic Belt (compared to actualistic examples from the Western Pacific): Episodes, 34( 4), 186-194.

Safonova, I.Yu., 2009. Intraplate magmatism and oceanic plate stratigraphy of the Paleo-Asian and Paleo-Pacific Oceans from 600 to $140 \mathrm{Ma}$. Ore Geology Reviews 35, 137-154.

Wang, T., Jahn, B. M., Kovach, V. P., Tong, Y., Hong, D. W., and Han, B. F., 2009. Nd-Sr isotopic mapping of the Chinese Altai and implications for continental growth in the Central Asian Orogenic Belt. Lithos, 110(1-4), 359-372.

Windley, B. F., Alexeiev, D., Xiao, W. J., Kröner, A., Badarch, G., 2007. Tectonic models for accretion of the Central Asian Orogenic Belt. Journal of the Geological Society, London, 164(1), 31-47.

Xiao, W. J., Windley, B. F., Hao, J., Zhai, M. G., 2003, Accretion leading to collision and the Permian Solonker suture, Inner Mongolia, China: termination of the central Asian orogenic belt. Tectonics 22, 1014, doi: 10. 1029/2002TC001396.

Xiao, W., Huang, B., Han, C., Sun, S., and Li, J., 2010, A review of the western part of the Altaids: A key to understanding the architecture of accretionary orogens: Gondwana Research, 18,(2-3), 253-273.

Xu, B., Charvet, J., Chen, Y., Zhao, P., Shi G. Z., 2013. Middle Paleozoic convergent orogenic belts in Central Inner Mongolia (China): framework, kinematics, geochronology and implications for tectonic evolution of the Central Asian Orogenic Belt. Gondwana Research 23(4), 1342-1364.

Xu, B., Charvet, J., Chen, Y., Zhao, P., Shi, G., 2013. Middle Paleozoic convergent orogenic belts in western Inner Mongolia (China): framework, kinematics, geochronology and implications for tectonic evolution of the Central Asian Orogenic Belt. Gondwana Research 23, 1342-1364. 